\title{
IMPORTANT ROLE OF SUPERVISION AND ITS IMPACT ON PERFORMANCE OF MANPOWER AND TRANSMIGRATION DEPARTMENT OF EAST OKU
}

\author{
Helisia Margahana ${ }^{a^{*}}$ \\ ${ }^{a)}$ Sekolah Tinggi Ilmu Ekonomi Trisna Negara, Sumatera Selatan, Indonesia \\ ${ }^{*}$ Corresponding Author: helisiagaraika87@gmail.com
}

Article history: received 06 February 2020; revised 20 February 2020; accepted 23 February 2020

\begin{abstract}
Resources owned by agencies will not provide optimum results if they are not supported by human resources who have optimum performance. Assessing the quality of existing human resources can be measured by employee performance. Performance can be a means for an agency to measure the ability of employees in an agency. This study aims to determine and analyze the important role of supervision and its impact on employee performance of Manpower and Transmigration Office at the East OKU. The hypothesis proposed is the existence of a strong influence between supervision on employee performance of Manpower and Transmigration Office at the East OKU.From the calculation results obtained $r=0.368$. After consultation with conservative standards it turns out that 0.368 is located between $0.200-0.399$ which is included in the low correlation. Then to answer the hypothesis test proposed in the previous chapter has a relationship or not, then tested with a hypothesis test and obtained $t$ count $=1.118$. While the $t$ table value at the $95 \%$ confidence level for $(n-2)=1,860$. Then it can be seen that the t value of 1.118 is greater than the value of $t$ table that is $=1.860$, thus it means that $(\mathrm{Ho})$ can be accepted and $(\mathrm{Ha})$ rejected.
\end{abstract}

Keywords: Supervision; Performance

\section{INTRODUCTION}

An organization or company tries to manage its company properly and correctly, both in terms of management, the implementation of supervision needs to be considered starting from planning activities to the objectives to be achieved. Therefore, to achieve progress as expected in an organization, the organization must continue to improve and keep trying how the organization can be equal to other organizations and have employees who can work properly and can be relied on [1]. In this case, the internal control of an organization plays a very important role to provide assurance based on the implementation of the organization or company and the responsibilities through this accountability system have been carried out as expected. Basically, human capabilities are limited, while their needs are unlimited. To meet unlimited needs with limited ability to do work encourages people to divide jobs, duties, and responsibilities [2]. The same goes for the East OKU Manpower and Transmigration Office. Based on the facts, it can be seen that in the East OKU Manpower and Transmigration Office the employees are not maximal in creating and maintaining a good working atmosphere where in these agencies there is less harmonious cooperation between employees, relationships between top leaders who are concerned with their respective fields, causing gaps and occurring. lack of communication between one employee and another.

The phenomena above will affect the work patterns and morale of employees, in other words, employee motivation will decrease and in turn lead to an unhealthy organizational climate, so that the performance which is the goal of the organization cannot be achieved [3]. In an effort to overcome and prevent unwanted things, it is necessary to monitor the decision-making process taken by the company management [4]. However, teaching and learning activities have not been significantly affected. In practice, supervision in every field of work or activity requires a procedure, effective and efficient monitoring methods and techniques [5]. The resources owned by the agency will not provide optimal results if they are not supported by human resources who have optimum performance. Assessing the quality of existing human resources can be measured from employee performance. Employee performance is the work ability achieved and desired from employee behavior in carrying out and completing work tasks that are the responsibility of individually or in groups [6]. In such situations, roles are needed. a leader who is able to generate work motivation and change an unhealthy organizational climate. The role of leadership here relates to making policies that are acceptable to all parties [7]. If all members of the organization, namely employees and leaders, have the same vision and mission, it is very easy to trigger their motivation to work better, so as to create a conducive organizational climate and in turn performance can increase [8].

\section{RESEARCH METHODS}

\section{Data source}

Primary Data.That is, data obtained directly from research activities. Data were collected from respondents by interview or filling in a prepared questionnaire. Secondary Data. That is, data obtained from outside research that comes from college books that have something to do with research [9]. 


\section{Data Collection and Processing}

\section{Library Research}

Namely data collection by studying various kinds of literature, scientific books related to research [10].

2. Field Research (Field Research)

Namely research that comes directly to the object of research to see and research directly. Done by :

a. Observation

Namely data collection by direct observation at the research location, namely the East OKU Manpower and Transmigration Office.

b. Questionnaire

Collecting data by providing a list of questions to leaders or employees of the East OKU Manpower and Transmigration Office.

c. Interview

Namely data collection by conducting direct interviews with researchers with leaders and lecturers who are considered to provide the information needed in the study.

d. Documentation

Namely the data obtained by looking at documents or records relating to research.

\section{Data Analysis}

1. Qualitative Analysis

The analysis used to solve existing problems is not using numbers as a basis for consideration, but by using sentences that describe the situation of the East OKU Manpower and Transmigration Office.

2. Quantitative Analysis

That is an analysis using numbers which aims to determine the size of the effect of supervision on employee performance at the East OKU Manpower and Transmigration Office.

\section{RESULTS AND DISCUSSION}

For this analysis, table tools and the correlation coefficient formula are used, with the initial step being the table obtained from the answers to the research questionnaire regarding the effect of supervision on employee performance at the East OKU Manpower and Transmigration Office. Thus, the work steps can be seen in the following tables :

Table 1. Variable (X) Supervision

\begin{tabular}{|c|c|c|c|c|c|c|}
\hline \multirow{2}{*}{ RESPONDENTS } & \multicolumn{5}{|c|}{ INSTRUMENT } & \multirow{2}{*}{ TOTAL } \\
\cline { 2 - 5 } & $\mathbf{1}$ & $\mathbf{2}$ & $\mathbf{3}$ & $\mathbf{4}$ & $\mathbf{5}$ & \\
\hline 1. & 3 & 2 & 3 & 2 & 3 & 13 \\
2. & 2 & 3 & 3 & 3 & 3 & 14 \\
3. & 3 & 2 & 3 & 3 & 2 & 13 \\
4. & 2 & 2 & 3 & 2 & 3 & 12 \\
5. & 3 & 3 & 2 & 3 & 3 & 14 \\
6. & 3 & 2 & 3 & 2 & 3 & 13 \\
7. & 3 & 2 & 3 & 2 & 3 & 13 \\
8. & 2 & 3 & 3 & 3 & 1 & 12 \\
9. & 2 & 3 & 3 & 2 & 3 & 13 \\
10. & 3 & 3 & 3 & 3 & 3 & 15 \\
\hline TOTAL & \multicolumn{7}{|c|}{} & $\mathbf{1 3 2}$ \\
\hline
\end{tabular}

Source: Processed Data
Table 2. Variable (Y) Performance

\begin{tabular}{|c|c|c|c|c|c|c|}
\hline \multirow{3}{*}{ RESPONDENTS } & \multicolumn{5}{|c|}{ INSTRUMENT } & \multirow{2}{*}{ TOTAL } \\
\cline { 2 - 6 } & $\mathbf{1}$ & $\mathbf{2}$ & $\mathbf{3}$ & $\mathbf{4}$ & $\mathbf{5}$ & \\
\hline 1. & 3 & 2 & 3 & 2 & 3 & 13 \\
2. & 2 & 3 & 3 & 3 & 3 & 14 \\
3. & 3 & 2 & 3 & 2 & 2 & 12 \\
4. & 2 & 2 & 3 & 2 & 3 & 12 \\
5. & 3 & 3 & 2 & 3 & 3 & 14 \\
6. & 3 & 2 & 3 & 2 & 3 & 13 \\
7. & 3 & 2 & 3 & 2 & 3 & 13 \\
8. & 2 & 3 & 3 & 3 & 1 & 12 \\
9. & 2 & 3 & 3 & 2 & 3 & 13 \\
10. & 2 & 3 & 3 & 2 & 3 & 13 \\
\hline \multicolumn{7}{|l|}{ TOTAL } \\
Source Processed Datan
\end{tabular}

Table 3. Correlation of Variable $X$ (Supervision) and Variable Y (Performance)

\begin{tabular}{|c|c|c|c|c|c|}
\hline No. & $\mathbf{X}$ & $\mathbf{Y}$ & $\mathbf{X}^{\mathbf{2}}$ & $\mathbf{Y}^{\mathbf{2}}$ & $\mathbf{X . Y}$ \\
\hline 1. & 13 & 13 & 169 & 169 & 169 \\
2. & 14 & 14 & 196 & 196 & 196 \\
3. & 13 & 12 & 169 & 144 & 156 \\
4. & 12 & 12 & 144 & 144 & 144 \\
5. & 14 & 14 & 196 & 196 & 196 \\
6. & 13 & 13 & 169 & 169 & 169 \\
7. & 13 & 13 & 169 & 169 & 169 \\
8. & 12 & 12 & 144 & 144 & 144 \\
9. & 13 & 13 & 169 & 169 & 169 \\
10. & 15 & 13 & 225 & 169 & 195 \\
\hline JUMLAH & $\mathbf{1 3 2}$ & $\mathbf{1 2 9}$ & $\mathbf{1 . 7 5 0}$ & $\mathbf{1 . 6 6 9}$ & $\mathbf{1 . 7 0 7}$ \\
\hline
\end{tabular}

Source: Processed Data

From the table above, the following results are obtained:

$$
\begin{array}{ll}
\mathrm{n}=10 & \mathrm{X}^{2}=1.750 \\
\mathrm{X}=132 & \mathrm{Y}^{2}=1.669 \\
\mathrm{Y}=129 & \mathrm{X} . \mathrm{Y}=1.707
\end{array}
$$

Then the values above are entered into the correlation coefficient formula as follows [11]:

\section{Correlation coefficient}

$$
\begin{aligned}
& r=\frac{n \cdot \sum X Y-\left(\sum X\right)\left(\sum Y\right)}{\sqrt{n \cdot \sum X^{2}-\left(\sum X\right)^{2} x \sqrt{n \cdot \sum Y^{2}-\left(\sum Y\right)^{2}}}} \\
& r=\frac{10(1707)-(132)(129)}{\sqrt{10(1.750)-(132)^{2}} \sqrt{10(1.669)-(129)^{2}}} \\
& I=\frac{(17070)-(17028)}{\sqrt{(17500)-(17424)} \cdot \sqrt{(16690)-(16641)}} \\
& I=\frac{42}{\sqrt{76} \sqrt{49}} \\
& I=\frac{42}{0,717.7} \\
& I=0,368
\end{aligned}
$$

Based on the results of statistical calculations obtained $r=0.368$. After consulting with conservative standards to determine whether the relationship is close or not, it turns out that it lies in the distance between 0.200 . 
0.399. It can be concluded that the effect of supervision on employee performance at the East OKU Manpower and Transmigration Office is low. To find out the percentage level between Variable $\mathrm{X}$ and the percentage level of Variable Y. Then use the following formula:

$$
\begin{aligned}
& \mathrm{r}=0,368 \\
& r^{2}=0,135 \\
& \mathrm{Kp}=\mathrm{r}^{2} \times 100 \% \\
& \mathrm{Kp}=(0,135) \times 100 \% \\
& \mathrm{Kp} \quad=13,5 \%
\end{aligned}
$$

By knowing the percentage level of the effect of supervision on employee performance $=13.5 \%$, it means that other factors that affect the performance of employees at the East OKU Manpower and Transmigration Service are $100 \%$ - Kp $(100 \%-13.5 \%)$, which is $86,5 \%$.

$$
\begin{aligned}
& \frac{r \sqrt{n-2}}{\sqrt{1-r^{2}}} \\
& \text { 'alpha }=0,05 \\
& \mathrm{t}=(\mathrm{n}-2)=\mathrm{t} \quad 0,05(\mathrm{n}-2) \\
& =\mathrm{t} 0,05(10-2) \\
& =\mathrm{t} 0,05(8) \\
& \mathrm{t}=1,860 \ldots \ldots . . \mathrm{t} \text { table } \\
& r=0,368 \\
& r^{2}=0,135 \\
& \mathrm{t}=\frac{0,368 \cdot \sqrt{10-2}}{\sqrt{1-0,135}} \\
& t=\frac{0,368 \cdot \sqrt{8}}{\sqrt{0,865}} \\
& \mathrm{t}=\frac{0,368(2,828)}{0,930} \\
& \mathrm{t}=\frac{1,040}{0,930} \\
& \mathrm{t}=1,118
\end{aligned}
$$

From the results of the above calculations, it can be seen that the $\mathrm{t}$ value $=1.118$. While the value of $\mathrm{t}$ table at the $95 \%$ confidence level for $(n-2)=1,860$. So it can be seen that the value of $\mathrm{t}$ count 1.118 is greater than the value of $\mathrm{t}$ table, namely $=1.860$, thus means (Ho) can be accepted and (Ha) rejected. This means that the hypothesis proposed is acceptable, namely that the supervision of the performance of employees at the East OKU Manpower and Transmigration Office is low.

\section{CONCLUSION}

The correlation between supervision of employee performance at the East OKU Manpower and Transmigration Office has a low effect, because the number $\mathrm{r}=0.368$ is obtained. After being consulted with the conservative standard, it turns out that 0.368 lies between $0.200-0.399$ which is included in the low correlation. So it can be said that there is a low influence between supervision on employee performance at the East OKU Manpower and Transmigration Office. To answer the hypothesis that has been put forward in the previous chapter by using the hypothesis test formula, obtained $(\mathrm{t})$ table $=1,860$ while $(\mathrm{t})$ arithmetic $=1,118$ which can be concluded that $(\mathrm{t})$ arithmetic $<(t)$ table or ( $t$ count is smaller than $t$ table), so that the hypothesis proposed in the previous chapter is proven or Ho is accepted and $\mathrm{Ha}$ is rejected, because the existing correlation is low.

\section{Suggestion}

To the East OKU Manpower and Transmigration Office, so that employee performance can be increased, the leadership should focus more attention on the Ability and Knowledge of Leadership Management so that the leadership will be more effective and not monotonous so that it can also have an impact on a more conducive and effective Organizational Culture. High motivation to stimulate employees to improve their performance in the East OKU Manpower and Transmigration Office. Leadership in accordance with the theory to be applied is a type of transformational leadership, considering that the East OKU Manpower and Transmigration Office is experiencing a period of recovery from a static situation to a dynamic situation.

\section{REFERENCES}

[1] Rivai. Kepemimpinan dan Perilaku Organisasi. Jakarta: PT. Raja Grafindo Persada. 2014.

[2] Malayu SP Hasibuan, Manajemen Dasar, Pengertian dan Masalah, Bandung : Bumi Aksara, 2011

[3] E.M.R. Sondole., O.S. Nelwan., I.D. Palandeng. Pengaruh Disiplin Kerja, Motivasi Dan Pengawasan Terhadap Kinerja Karyawan Pada Pt. Pertamina (Persero) Unit Pemasaran VII, Terminal Bbm Bitung. Jurnal EMBA Vol.3 No.3 Sept. 2015, Hal.650-659.

[4] Adil Ridlo Fadillah, Analisis Pengaruh Dewan Komisaris Independen, Kepemilikan Manajerial Dan Kepemilikan Institusional Terhadap Kinerja Perusahaan Yang Terdaftar Di Lq45. Jurnal Akutansi. Volume 12, Nomor 1, Januari-Juni . 2017

[5] Elly Nielwaty, Prihati, Sulaiman Zuhdi, Pengaruh Pengawasan Terhadap Kinerja Pegawai Disperindag Sub Bidang Pengawasan Barang Dan Jasa Provinsi Riau. Jurnal Ilmu Ekonomi \& Bisnis.Vol. 10, No. 1 Juli. 2017, Hal. 1-5

[6] Herawati., Suputra., dan Budiasih. Pengaruh Pengawasan Pimpinan, Disiplin dan Kompetensi 
Pegawai pada Kinerja Pegawai Inspektorat Kabupaten Tabanan.ISSN : E-JURNAL Ekonomi dan Bisnis 2337- 3067 Universitas Udayana 5.7. 2016

[7] Sudarmin Manik, Pengaruh Kompetensi Terhadap Kinerja Dosen Sekolah Tinggi Ilmu Ekonomi Riau. Jurnal Ilmiah Ekonomi dan Bisnis Vol. 15. No.1, Maret 2018: 1-6

[8] Regina Amanda, Pengaruh Pengawasan Terhadap Kinerja Karyawan Melalui Disiplin Kerja Sebagai Variabel Intervening Di Pt Astra International Tbk Waru Pada Bagian Part \& Accessories (Depo).Jurnal Ilmu Manajemen (JIM). Vol 4, No 4. 2016.

[9] Sugiyono, Statistik Untuk Penelitian, Alfabeta, Bandung, 2011

[10] Sumadi Suryabrata, Metodologi Penelitian, Jakarta : PT. Raja GrafindoPersada, 2011

[11] Riduwan, Dasar-Dasar Statistika, Alfabeta, Bandung : 2010 